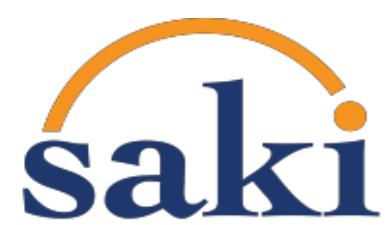

\title{
Analisis Pengaruh Struktur Modal Terhadap Praktik Manajemen Laba
}

\author{
Ines Devina*, Sandy Harianto, Johan Yanto \\ Sekolah Bisnis dan Ekonomi - Universitas Prasetiya Mulya \\ BSD City Kavling Edutown I.1 , Jl. BSD Raya Utama, BSD City, Tangerang 15339
}

Keywords:

Capital

Structure,

Earnings Management,

Discretionary Accruals

Kata Kunci:

Struktur

manajemen

modal,

discretionary accruals.

*Corresponding Author:

Ines_devina@yahoo.co.id

\begin{abstract}
The research objective is to analyze the influence of capital structure to earnings management practices. The research using multiple regressions examined 192 non-financial companies listed on Indonesia Stock Exchange from 2005 to 2014 period. The proxies of capital structure are debt-to-equity ratio and debt-to-asset ratio, while earnings management calculated through discretionary accruals from Jones, Modified Jones, cross-sectional industrial models.The results showed that there is a negative significant influence from firm's capital structure to earnings management ( $\alpha$ <0.05). This indicates that higher use of debt would increase the difficulties of debt covenant performance requirements; hence it increases the degree of control over the company, leaving less opportunity for earnings management.
\end{abstract}

\section{Abstrak}

Tujuan penelitian adalah menganalis is pengaruh struktur modal terhadap praktik manajemen laba. Penelitian ini diuji menggunakan regresi berganda dengan sampel 192 perusahaan non-finansial yang terdaftar pada Bursa Efek Indonesia periode 2005-2014. Proksi struktur modal adalah debt-to-equity ratio dan debt-to-asset ratio, sedangkan variabel manajemen laba dihitung melalui discretionary accruals model Jones, Modified Jones, dan cross-sectional industrial. Hasil penelitian menunjukkan bahwa struktur modal berpengaruh negatif signifikan terhadap manajemen laba $(\alpha<0,05)$. Hal ini mengindikasikan bahwa semakin tingginya penggunaan utang yang menyebabkan semakin ketatnya debt covenant, kontrol dari perusahaan atas performa perusahaan semakin tinggi, sehingga ruang bagi manajemen untuk melakukan manajemen laba semakin sedik it. 


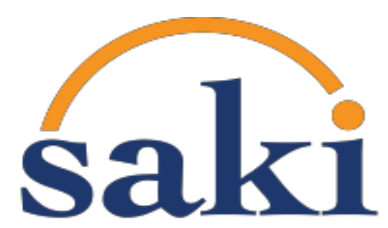

\section{Pendahuluan}

Tak bisa dipungkiri bahwa berkembangnya perusahaan harus didukung oleh pendanaan yang memadai baik dari utang, ekuitas, atau kombinasi keduanya. Hal ini dikarenakan seiring meningkatnya kapasitas operasional perusahaan, kebutuhan akan pendanaan pun terus meningkat, namun risiko bangkrutnya perusahaan juga semakin meningkat. Karenanya, diperlukan kombinasi antara penggunaan utang dan ekuitas yang sesuai dengan kebutuhan dan kapabilitas perusahaan.

Struktur modal merupakan perbandingan antara utang terhadap ekuitas suatu perusahaan, dan sering kali diproksikan dengan debt-to-equity ratio, yang mencerminkan kombinasi penggunaan utang dan ekuitas yang dimiliki perusahaan. Pengelolaan struktur modal dibutuhkan untuk mendapatkan kombinasi pendanaan yang optimal bagi perusahaan. Pengelolaan ini penting karena berkaitan erat dengan pembelanjaan perusahaan itu sendiri. Tanpa kapabilitas perusahaan untuk mendapatkan modal yang sesuai dengan kapasitasnya, perusahaan dapat terancam tidak dapat melakukan pembelanjaan yang dibutuhkan. Rencana pembelanjaan yang disusun meliputi penentuan struktur modal yang akan digunakan, serta perimbangan pembelanjaan yang sesuai dengan struktur modal yang dimiliki perusahaan (Riyanto, 1990 dalam Kesuma, 2009).

Dalam teori struktur modal optimal atau trade off theory of leverage (Gardner, McGowan, \& Moeller, 2013), dipertimbangkan bahwa peningkatan utang bukan hanya membawa manfaat bagi perusahaan yakni penghematan pajak, namun juga terdapat biaya yang muncul dan justru dapat menyebabkan risiko kebangkrutan perusahaan menjadi sangat tinggi karena penghematan yang didapatkan perusahaan tidak sebanding dengan biaya yang timbul tersebut. Biaya tersebut harus diperbandingkan dengan manfaat dari penggunaan utang, sehingga didapat struktur modal yang optimal, yakni disaat manfaat dari penghematan pajak memiliki keseimbangan dengan biaya kesulitan keuangan (financial distress) dan biaya keagenan (agency costs), yang dijelaskan melalui tradeoff theory of leverage.

Biaya kesulitan keuangan muncul disaat penggunaan utang yang tinggi membuat perusahaan terancam mengalami kegagalan pembayaran yang kemudian dapat menyebabkan perusahaan mengalami kebangkrutan. Selain itu terdapat pula biaya keagenan yang timbul dari utang karena diperlukannya pengawasan pada manajer untuk tidak melakukan tindakan yang dapat merugikan kreditor, sesuai dengan debt covenant atau persyaratan kontrak utang.

Struktur modal yang optimal memiliki bentuk kurva non-linier, membentuk parabola terhadap nilai. Titik tertinggi dari parabola merupakan disaat perusahaan mencapai struktur modalnya yang optimal, dimana berada pada level penggunaan utang tertinggi sebatas penghematan pajak masih dapat mengimbangi biaya kesulitan keuangan dan biaya keagenan (Scott, 1976). Titik optimal dari struktur 
modal tersebut dapat menghasilkan WACC yang teroptimal bagi perusahaan (Chakraborty \& Sen, 1975). Karena itu, menurut teori struktur modal optimal, struktur modal memiliki pengaruh terhadap nilai perusahaan yakni dari adanya penghematan pajak yang apabila berimbang dengan biaya yang timbul dari utang, akan membantu menghemat WACC perusahaan, yang meningkatkan nilai dari perusahaan.

Motivasi adanya penghematan bagi perusahaan serta untuk mencapai titik optimal dari struktur modal dapat memotivasi penggunaan utang yang semakin tinggi. Semakin besarnya pinjaman membuat kreditor memiliki suatu kepentingan terhadap perusahaan. Hal ini dapat menyebabkan timbulnya suatu problema keagenan yang terjadi antara dua kepentingan, yakni pemegang saham perusahaan dan kreditor.

Konflik kepentingan terjadi disaat pemegang saham menginginkan penggunaan dana dialokasikan untuk proyek yang berisiko karena akan memberikan pengembalian yang tinggi apabila sukses. Namun, kreditor menginginkan hal sebaliknya, yakni perusahaan tidak melaksanakan proyek yang berisiko tinggi karena khawatir perusahaan akan mengalami kemacetan pembayaran. Apabila proyek berisiko tinggi tersebut mengalami kesuksesan, pemegang sahamlah yang akan merasakan dampak keuntungan yakni pengembalian investasi yang lebih tinggi, namun bila justru mengalami kegagalan, perusahaan akan terancam merugi hingga tidak dapat membayarkan pinjaman dan bunga pada kreditor (Haugen \& Senbet, 1988).

Problema keagenan karena adanya konflik kepentingan ini dapat menyebabkan dipraktikannya manajemen laba oleh perusahaan. Manajemen laba sendiri adalah tindakan yang disengaja, yang bertujuan untuk mempengaruhi proses pelaporan keuangan perusahaan demi mendapatkan keuntungan bagi pribadi (manajemen) dibaliknya (Healy \& Wahlen, 1999). Karenanya, untuk melindungi kepentingannya, kreditor membuat suatu kontrak yang berisi persyaratan bagi perusahaan yang mengharuskan perusahaan mencapai suatu performa ataupun melarang perusahaan untuk melakukan tindakan yang dapat merugikan kreditor (Longhofer \& Peters, 2004). Kontrak ini disebut dengan debt covenant.

Dengan adanya debt covenant, manajer harus mengupayakan terjaganya posisi keuangan perusahaan yang sesuai dengan debt covenant tersebut. Dalam menjaga posisi keuangan tersebut, manajer dapat terdorong untuk melakukan manajemen laba, terlebih disaat posisi keuangan perusahaan terancam tidak memenuhi persyaratan debt covenant. Tindakan manajemen laba ini dapat mengurangi ketepatan dan keandalan informasi dalam laporan keuangan yang penting bagi calon investor dan kreditor dalam menilai pengembalian yang dapat diberikan perusahaan sebelum memberikan dana, ataupun pengguna 
laporan keuangan lainnya. Hal ini dapat merugikan pengguna laporan keuangan, karena bersifat menyesatkan penggunanya.

Menurut Davidson, Goodwin-Stewart, \& Kent (2005) adanya kenaikan leverage, yang berarti naiknya penggunaan utang atas total aset perusahaan, maka semakin tinggi kemungkinan dilakukannya manajemen laba. Hal ini dikarenakan manajer memiliki risiko pelanggaran debt covenant, yang dapat membuat perusahaan berhenti mendapatkan dana dari utang, sehingga tercipta insentif bagi manajer untuk melakukan manajemen laba. (Kim, Lisic, \& Pevzner, 2011).

Namun, adanya debt covenant dapat justru mengurangi praktik dari manajemen laba. Hal ini dikarenakan pengawasan yang bertambah secara kuantitatif dan kualitatif. Secara kuantitatif, kreditor menjadi ikut mengawasi kinerja manajemen dan secara kualitatif, komisaris perusahaan juga ikut meningkatkan pengawasannya agar kinerja perusahaan tidak menurun yang dapat menyebabkan perjanjian peminjaman dana menjadi batal. Karena itu, ruang bagi manajer untuk melakukan manajemen laba menjadi semakin sedikit. (Becker, DeFond, Jiambalvo, \& Subramanyam, 1998; Chen, Elder, \& Hsieh, 2005; Jelinek, 2007)

Penelitian dari Chung, Firth, dan Kim (2005) menje laskan bahwa dengan adanya debt covenant dari penggunaan utang sebagai sumber dana, performa dari manajer lebih terkontrol karena tuntutan yang tinggi untuk terhindari dari pelanggaran debt covenant. Hal ini sejalan dengan penelitian yang dilakukan oleh King dan Santor (2008), yang menemukan bahwa digunakannya utang sebagai sumber pendanaan adalah untuk control-enhancing mechanism, terlebih pada perusahaan yang kepemilikannya lebih terkonsentrasi. Dengan adanya debt covenant, perusahaan menjadi memiliki insentif yang tidak dimiliki oleh perusahaan tanpa pendanaan utang (Grossman dan Hart, 1982). Penggunaan utang ini membuat manajer memberikan performa yang lebih baik dalam meningkatkan nilai perusahaan, dikarenakan adanya biaya kebangkrutan yang sebelumnya tidak dipandang oleh manajer tersebut.

Sehingga, dapat dis impulkan bahwa struktur modal dapat berpengaruh pada praktik manajemen laba, baik berpengaruh positif maupun pengaruh negatif. Penelitian ini ingin menjawab apakah benar adanya pengaruh signifikan dari struktur modal terhadap manajemen laba pada perusahaan nonfinansial yang terdaftar dalam Bursa Efek Indonesia di tahun 2005-2014. Hasil penelitian ini menunjukkan bahwa struktur modal berpengaruh negatif terhadap manajemen laba. Artinya, semakin tinggi utang perusahaan, maka semakin kecil tendensi dilakukannya manajemen laba. Pengawasan yang meningkat dari kreditor terbukti membatasi diskresi manajemen untuk melakukan manajemen laba. 
Struktur dari paper ini disajikan sebagai berikut: bagian kedua memuat kajian pustaka tentang struktur modal optimal, konflik kepentingan antara shareholder dan debtholder, serta manajemen laba. Bagian ketiga memuat metode penelitian yang berisi sampel dan operasionalisasi variabel. Bagian keempat memuat hasil statistik deskriptif, uji hipotesis, dan diskusi. Bagian terakhir memuat kesimpulan, saran, dan keterbatasan

\section{Telaah Literatur dan Pengembangan Hipotesis}

\section{Struktur Modal Optimal}

Gardner, McGowan, \& Moeller (2013) menjelaskan bahwa struktur modal yang optimal dijelaskan melalui tradeoff theory of leverage. Struktur modal yang optimal akan didapatkan di saat terjadi keseimbangan antara penghematan pajak dari biaya bunga pinjaman yang bersifat tax deductible expense dengan biaya yang timbul dari penambahan penggunaan utang tersebut (Bradley, Jarrell, \& Kim, 1983). Disaat penghematan (manfaat) dan biaya kesulitan keuangan (biaya) dapat saling meniadakan, disaat itulah perusahaan memiliki struktur modal yang optimum.

Perusahaan yang menggunakan utang akan mendapatkan manfaat yakni berkurangnya beban pajak perusahaan dari bunga pinjaman yang termasuk tax deductible expense. Penghematan ini memotivasi perusahaan untuk menggunakan utang pada level tertentu. Namun, penghematan ini dapat dirasakan manfaatnya hanya sampai suatu titik, yang disebut dengan titik optimal dari struktur modal perusahaan. Robichek \& Myers (1966) menjelaskan bahwa manfaat dari keunggulan penggunaan utang yakni adanya pengurangan biaya pajak terbatas sehingga manfaat tersebut dapat mengimbangi biaya yang timbul dari penggunaan utang.

Biaya yang timbul dari penggunaan utang biasanya adalah biaya financial distress atau kesulitan keuangan yang timbul dari meningkatnya risiko kebangkrutan perusahaan. Contoh dari biaya kesulitan keuangan adalah penjualan aset dibawah harga pasar untuk mendapatkan dana tambahan, biaya likuidasi perusahaan, serta bisa hilangnya legalitas dari perusahaan. Biaya lain yang dapat timbul dari penggunaan utang adalah biaya keagenan dari penggunaan utang (agency cost of debt). Biaya keagenan dari penggunaan utang berkaitan dengan pengawasan dan pengendalian tindakan manajemen perusahaan. Biaya ini timbul karena kreditor membuat debt covenant yang didalamnya terdapat persyaratan yang harus dipenuhi sehingga dilakukan pengawasan yang lebih ketat agar manajer tidak memanfaatkan asimetri informas inya mengenai prospek perusahaan. Kedua biaya inilah 
yang membatasi penggunaan utang, sehingga penggunaan utang yang berlebih dapat justru membuat biaya lebih tinggi dibandingkan dengan manfaat dari penghematan pajak perusahaan.

Penggunaan struktur modal di titik optimal menghasilkan WACC yang juga optimal bagi perusahaan (Chakraborty \& Sen, 1975). Penggunaan modal dari utang yang berlebih dapat menyebabkan pengembalian yang diekspektasi oleh pemegang saham menjadi lebih tinggi, karena pemegang saham mempunyai harapan bertambahnya pengembalian disaat risiko kebangkrutan perusahaan lebih tinggi karena bertambahnya penggunaan utang. Penggunaan utang yang melebihi struktur modal optimal dapat menyebabkan biaya kesulitan keuangan yang dilihat sebagai risiko kebangkrutan oleh pemegang saham menjadi lebih tinggi dibandingkan dengan manfaatnya, karena itu ekspektasi pengembalian dari pemegang saham justru menjadi lebih tinggi sehingga Ke (cost of debt) membuat WACC perusahaan lebih tinggi dari sebelum menggunakan utang.

Dengan kondisi adanya penghematan pajak dari bunga pinjaman yang adalah tax deductible expense dan biaya dari utang yang adalah biaya kesulitan keuangan (financial distress), penggunaan utang akan menurunkan WACC hingga titik tertentu yakni disaat titik struktur modal optimal dicapai. Namun, peningkatan penggunaan utang di atas titik optimal justru akan menyebabkan WACC dari perusahaan lebih tinggi.

Karena itu, berbeda dengan Modigliani dan Miller (1963), struktur modal perusahaan berpengaruh pada nilai perusahaan dan WACC. Sehingga, target untuk mencapai struktur modal yang optimal dapat memotivasi penggunaan utang bagi perusahaan agar dapat menghemat biaya modal perusahaan juga.

\section{Konflik Kepentingan antara Shareholders \& Debtholder}

Penggunaan utang yang lebih tinggi dapat meningkatkan kepentingan dari kreditor terhadap perusahaan, yang karenanya, dapat menimbulkan problem keagenan antara pemegang saham (shareholders) dengan kreditor (debtholder). Teori Keagenan tipe ketiga menjelaskan mengenai adanya konflik kepentingan antara Pemegang Saham perusahaan dengan Kreditor.

Hill \& Jones (1992) menjelaskan konflik kepentingan terjadi karena masing-masing kepentingan bertindak mementingkan kepentingannya masing-masing. Pemegang saham mementingkan bagaimana perusahaan mendapatkan laba yang tinggi, yaitu salah satunya dengan cara menambah proyek-proyek yang memiliki risiko yang tinggi sehingga pendanaan yang didapat dari kreditor didorong untuk digunakan pada proyek tersebut (Frierman \& Viswanath, 1994). Di sisi lain, kreditor mementingkan kemampuan perusahaan agar dapat melakukan pembayaran pinjaman dan bunga. Karena itu, kreditor justru menghindari mendanai proyek yang berisiko tinggi tersebut. Hal tersebut 
dikarenakan disaat proyek tersebut membuahkan hasil yang sukses, keuntungan didapat bagi pemegang saham yakni melalui bertambahnya dividen, sedangkan pembayaran pinjaman dan bunga kepada kreditor tidak bertambah; namun, jika mengalami kegagalan, kreditor-lah yang mengalami kerugian dimana terancam tidak mendapat pembayaran pinjaman dan bunga (Mao, 2003).

Karenanya, kreditor seringkali membatasi penggunaan dana yang dipinjamkan pada perusahaan. Dana perusahaan dilarang digunakan untuk membayarkan dividen, untuk pendanaan proyek yang memiliki risiko tinggi, dan juga tidak memperbolehkan perusahaan melakukan tindakan yang dapat merugikan kreditor. Perjanjian tersebut tertulis pada debt covenant atau persyaratan kontrak utang antara perusahaan dan kreditor (Longhofer \& Peters, 2004). Perbedaan kepentingan ini dapat mendorong adanya tindakan manajemen laba. Kesulitan dalam memenuhi debt covenant dapat mendorong manajemen untuk melakukan manajemen laba yang akhirnya berdampak pada manipulasi informasi keuangan. Atau justru, debt covenant dapat mengurangi praktik manajemen laba, yang dikarenakan adanya debt covenant meningkatkan fungsi pengawasan terhadap kinerja perusahaan.

\section{Manajemen Laba}

Menurut Healy \& Wahlen (1999), manajemen laba adalah tindakan yang disengaja, yang bertujuan untuk mempengaruhi proses pelaporan keuangan perusahaan demi mendapatkan keuntungan bagi kepentingan pribadi (manajemen). Manajemen laba dilakukan dengan merubah informasi laporan keuangan untuk memberikan informasi yang berbeda bagi penggunanya, sehingga informasi keuangan yang disajikan menjadi bersifat menyesatkan bagi penggunanya.

Dasar dari adanya praktik manajemen laba adalah teori agensi, yang menjelaskan mengenai adanya perbedaan kepentingan antara agen dan prinsipal dalam melakukan tanggung-jawabnya, ataupun antara pihak mayoritas dengan minoritas, hingga antara pihak internal perusahaan dan eksternal perusahaan. Scott (2000) melalui Omid (2012) memberikan contoh yakni teori agensi dikorelasikan dengan sikap oportunis manajer terhadap berbagai kompensasi dengan memaksimalkan utilitas yang dimiliki manajer tersebut.

\section{Pengembangan Hipotesis}

Menurut Kim, et al. (2011) pada penelitiannya terhadap 2.810 data observasi di Amerika Serikat, manajer memiliki kecenderungan untuk terdorong melakukan manajemen laba disaat terancam terlanggarnya debt covenant dikarenakan situasi finansial perusahaan yang berubah. Artinya, struktur modal berpengaruh positif terhadap manajemen laba.

Penelitian dari Chung, et al. (2005) menjelaskan dalam penelitian atas 22.576 data observasi dari Global Compustat Data (1980-1996), menemukan hasil sebaliknya dari Kim, et al. (2011), bahwa 
mela lui debt covenant, kontrol terhadap performa perusahaan dalam meningkatkan nilai menjadi lebih tinggi. Dampak berupa tekanan ini sama seperti yang ditemukan oleh King dan Santor (2008), yang dari penelitian atas 613 perusahaan di Kanada tahun 1998-2005, mengemukakan fungsi controlenhancing mechanism pada perusahaan yang tadinya hanya menggunakan pendanaan ekuitas. Fungsi tersebut terletak pada risiko kebangkrutan yang timbul jika debt covenant terus menerus dilanggar.

Beberapa penelitian menemukan bahwa pengaruh dari debt covenant terhadap manajemen laba adalah negatif, dimana semakin tinggi unsur utang, semakin rendah tingkat praktik manajemen laba (Becker et al, 1998; Chen et al., 2005; Jelinek, 2007). Sedangkan penelitian lain menemukan pengaruh yang positif dimana unsur utang yang tinggi dalam struktur modal mendorong dilakukannya manajemen laba (Jeanjean, 2000; Klein, 2002; Davidson, et al., 2005; Jaggi et al., 2009). Penelitian di Indonesia yang menemukan pengaruh positif dari struktur modal terhadap manajemen laba diantaranya adalah Widyaningdyah (2001), Astuti (2006), dan Budiasih (2008).

Di tahun 2007, Jelinek meneliti 14.322 data observasi 1992-2002 untuk menguji efek dari adanya kenaikan leverage terhadap manajemen laba di Amerika Serikat. Adanya kenaikan leverage berpengaruh negatif terhadap manajemen laba. Sama seperti penelitian dari Becker et al. (1998) dan Chung et al. (2005), variabel kualitas audit juga berpengaruh negatif signifikan.

Salah satu penelitian lainnya dilakukan oleh Davidson et al. (2005), dimana penelitian dilakukan terhadap 434 perusahaan di Australia pada laporan keuangan tahun 2000. Hasil penelitian menunjukkan bahwa struktur modal yang diproksikan dengan DER, ukuran perusahaan, adanya komite audit, dan independennya dewan komisaris berpengaruh signifikan pada praktik manajemen laba secara parsial dan simultan. Sedangkan, variabel yang insignifikan adalah struktur kepemilikan, kualitas audit, dan fungsi audit internal.

Penelitian lainnya dari Kim dan Yi (2005). Di tahun yang sama dengan Davidson et al. (2005), Kim dan Yi (2005) melakukan penelitian terhadap 15.159 observasi (non-finansial) tahun 1992 hingga 2000. Hasil penelitian mengindikasikan bahwa struktur kepemilikan, struktur modal, ukuran perusahaan, kualitas audit, profitabilitas, dan status perusahaan publik atau-pun privat memiliki pengaruh yang signifikan, baik secara simultan maupun parsial. Kualitas audit dalam penelitian ini ditemukan signifikan, sama seperti penelitian dari Klein (2002).

Jaggi et al. (2009) meneliti pengaruh independensi komisaris terhadap praktik manajemen laba di Hong Kong tahun 1998-2000. Peneliti menemukan bahwa pengaruh dari independensi komisaris sendiri adalah negatif signifikan. Kemudian, variabel kontrol CEO Duality adalah negatif sinsignifikan, kualitas audit negatif insignifikan, ukuran perusahaan negatif signifikan, serta 
profitabilitas juga negatif signifikan. Untuk leverage, juga adalah variabel kontrol yang pengaruhnya positif signifikan terhadap manajemen laba.

Penelitian mengenai manajemen laba di Indonesia juga menemukan bahwa adanya pengaruh positif dan signifikan dari struktur modal perusahaan dengan manajemen laba. Widyaningdyah (2001) menemukan bahwa dari 51 perusahaan manufaktur tahun 1994 sampai 1997, struktur modal berpengaruh signifikan terhadap manajemen laba. Hal ini dikarenakan disaat terancam default, manajemen laba dilakukan guna memperbaiki posisi perusahaan. Penelitian Widyaningdyah (2001) menggunakan ukuran dari dewan direksi dan kualitas audit sebagai variabel kontrol sela in leverage atau struktur modal.

Kemudian, Astuti (2006) mengobservasi 34 perusahaan yang melakukan right issue selama 5 tahun observasi. Hasil dari penelitian adalah manajemen laba yang dilakukan sebelum right issue lebih tinggi dibandingkan setelahnya. Selain itu, peneliti juga menemukan bahwa leverage atau struktur modal berpengaruh signifikan terhadap manajemen laba yang dilakukan. Penemuan pengaruh struktur modal ini sama seperti yang ditemukan oleh Guna \& Herawaty (2010) yang meneliti 40 perusahaan manufaktur di Indones ia tahun 2006-2008. Pengaruh struktur modal adalah positif signifikan terhadap manajemen laba.

Struktur modal yang optimal dapat memberikan manfaat bagi nilai perusahaan dimana akan didapatkan WACC yang juga optimal. Karena itu, penggunaan utang menjadi termotivasi untuk mencapai titik optimal tersebut. Peningkatan penggunaan utang dapat menyebabkan timbulnya problema keagenan antara pemegang saham perusahaan dan kreditor, dimana kepentingan dari keduanya berbeda. Untuk melindungi kepentingan kreditor dari eksproriasi yang dilakukan pemegang saham melalui kontrolnya atas manajemen, kreditor membuat debt covenant atas perusahaan.

Adanya debt covenant dapat mempengaruhi praktik manajemen laba perusahaan. Untuk menghindari pelanggaran debt covenant, manajemen melakukan manipulasi informasi keuangan melalui manajemen laba terutama disaat performa perusahaan sedang menurun dan mengalami kesulitan dalam mempertahankan performa. Namun, hal sebaliknya juga dapat terjadi. Debt covenant yang meningkatkan fungsi pengawasan atas kinerja perusahaan justru membuat praktik manajemen laba semakin menurun karena celah diskresi justru semakin sempit.

Karena itu, hipotesis dari penelitian adalah sebagai berikut.

$\mathbf{H}_{1}$ : Struktur modal berpengaruh pada praktik manajemen laba. 


\section{Metode Penelitian}

\section{Data dan Pemilihan Sampel Penelitian}

Penelitian ini menggunakan data sekunder dari Bloomberg dan laporan keuangan perusahaan dari Bursa Efek Indonesia (BEI) periode 2005-2014. Pemilihan sampel dilakukan dengan teknik Purposive Sampling dengan kriteria berikut.

1. Perusahaan publik, yang terdaftar di Bursa Efek Indonesia.

2. Perusahaan memiliki nilai buku dari ekuitas yang adalah positif $(B V>0)$ selama periode penelitian.

3. Perusahaan bergerak di bidang non-finansial, sehingga perusahaan yang menjadi subjek penelitian adalah yang memiliki nomor sektor 1 sampai 9, kecuali 8 menurut pengklasifikasian Indeks JASICA.

4. Perusahaan berdiri dan sudah terdaftar di BEI sebelum tahun 2005, tidak pernah delisting selama periode, dan masih terdaftar di BEI setelah 2014, juga menerbitkan laporan keuangan lengkap selama periode penelitian.

Tabel 1. Eliminasi Populasi sesuai Kriteria Sampel

\begin{tabular}{|l|r|r|}
\hline \multicolumn{1}{|c|}{ Keterangan } & Jumlah perusahaan & $\begin{array}{c}\text { Jumlah } \\
\text { observasi }\end{array}$ \\
\hline Perusahaan publik, terdaftar di Bursa Efek Indonesia. & 525 & 5.250 \\
\hline Perusahaan memiliki nilai buku dari eku itas negatif $(\mathrm{BV}<0)$. & $(82)$ & $(820)$ \\
\hline Perusahaan bergerak di bidang finansial. & $(97)$ & $(970)$ \\
\hline $\begin{array}{l}\text { Perusahaan berdiri setelah tahun 2005, atau sudah tidak } \\
\text { terdaftar sebelum tahun 2014, atau mengalami delisting selama } \\
\text { periode, atau juga laporan keuangan tidak lengkap. }\end{array}$ & $(154)$ & $(1.540)$ \\
\hline Total & 192 & $\mathbf{1 . 9 2 0}$ \\
\hline
\end{tabular}

Dari eliminasi ini, didapatkan 192 perusahaan yang memenuhi kriteria tersebut, sehingga didapatkan jumlah 1.920 observasi.

\section{Operasionalisasi variabel}

\section{Variabel Dependen - Manajemen Laba}

Dalam mendeteksi manajemen laba, terdapat beberapa model yang sering digunakan baik oleh perusahaan maupun oleh peneliti, yakni:

\section{1. $\quad$ The Jones Model (1991)}

Model Jones melihat non discretionary accrual sebagai pengaruh dari beberapa variabel. 


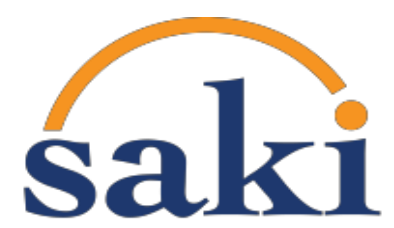

Total Akrual dihitung dengan net income before extraordinary items dikurangi dengan operating cash flow. Total akrual pertama-tama dibagi dengan total aset periode sebelumnya. Selanjutnya diregresi sesuai model dari Jones (1991) seperti persamaan dibawah. Setelah didapatkan koefisien $\alpha_{0}, \alpha_{1}$, dan $\alpha_{2}$, non-discretionary accruals dapat dihitung. Total akrual kemudian dikurangi non-dicretionary accruals, sehingga didapatkan discretionary accruals, yang merupakan indikator manajemen laba.

\section{2. $\quad$ The Modified Jones Model (1995)}

Menurut Dechow, Sloan, \& Sweeney (1995), model ini merupakan model yang paling andal karena dapat memberikan hasil yang paling relevan. Model ini mengeliminasi tendensi konjungtor yang adalah perubahan pada piutang perusahaan.

Koefisien yang digunakan dalam menghitung Discretionary Accruals Modified Jones Model adalah koefisien dari regresi dengan Jones Model (1991), disaat selisih revenue dengan periode sebelumnya belum dinetokan dari selisih receivable dengan periode sebelumnya.

\begin{tabular}{|l|l|l|}
\hline Dimana, & & \\
\hline$A C C R_{i t}$ & $:$ & total accrual di periode berjalan $=$ NIBE $-O C F$ \\
\hline$N D A_{i t}$ & $:$ & non-discretionary accruals di periode berjalan \\
\hline$\Delta R E V_{i t}$ & $:$ & selisih revenue periode berjalan den gan satu periode sebelumnya \\
\hline$\Delta R E C_{i t}$ & $:$ & selisih net receivable periode berjalan dengan satu periode sebelumnya \\
\hline$P P E_{i t}$ & $:$ & jumlah PPE di periode berjalan \\
\hline$A_{i t-1}$ & $:$ & total asset di periode sebelumnya \\
\hline$e_{i t}$ & $:$ & error (residual) \\
\hline$\propto_{0}, \propto_{1}, \propto_{2}$ & $:$ & koefisien \\
\hline
\end{tabular}

Pada penelitian ini, model yang digunakan untuk mendeteksi manajemen laba adalah Jones Model, Modified Jones Model dan Cross-sectional Industrial Jones Model \& Modified Jones Model, yang merupakan pengembangan kedua model menjadi industri adjusted (Siregar \& Utama, 2008). Keempat model digunakan karena memiliki hubungan, dimana Modified Jones Model merupakan model yang dikembangkan dari dasar Jones Model, dan cross-sectional industrial model merupakan pengembangan model yang menspesifikan akrual diskrisioner di setiap sektor industri.

Variabel Independen - Struktur Modal

Variabel independen yang digunakan adalah struktur modal, diproksikan dengan debt-to-equity ratio (DER), dan debt-to-asset (DAR). DER menggambarkan perbandingan penggunaan utang terhadap 
penggunaan ekuitas sebagai modal perusahaan. Sedangkan DAR menggambarkan perbandingan utang terhadap total aset perusahaan.

$$
\text { DER }=\frac{\text { Total Liabilitas }}{\text { Total Ekuitas }} ; \text { DAR }=\frac{\text { Total Liabilitas }}{\text { Total Aset }}
$$

\section{Variabel Kontrol}

Variabel kontrol pertama yang digunakan dalam penelitian adalah Ukuran Dewan Komisaris. Variabel ini diproksikan dengan jumlah komisaris yang dimiliki perusahaan setiap tahun. Xie, Davidson, \& DaDalt (2003) menemukan bahwa dengan jumlah komisaris yang lebih banyak, pengawasan menjadi lebih efektif dikarenakan jumlah komisaris yang lebih banyak mayoritas indentik dengan semakin banyaknya orang yang berpenga laman ikut mengawasi jalannya perusahaan.

Independensi Komisaris merupakan variabel kontrol kedua. Independensi Komisaris diproksikan dengan proporsi komisaris independen terhadap total komisaris perusahaan. Mengacu pada Komite Nasional Kebijakan Good Corporate Governance 2004, komite independen diharuskan tidak memiliki hubungan dengan manajemen, komisaris lainnya, ataupun pemegang saham pengendali, juga tidak memiliki hubungan bisnis dan lainnya yang dapat mendistorsi tindakan independennya atas perusahaan. Karena itu, dengan adanya komisaris independen, tindakan manajemen laba dapat lebih terbatasi. (Jaggi et al., 2009).

Kualitas audit juga merupakan salah satu variabel kontrol. Kualitas audir diukur dengan dummy dimana perusahaan menggunakan jasa KAP Big Four diberikan nilai 1, sedangkan perusahaan yang tidak menggunakan jasa KAP Big Four diberikan nilai 0. Becker et al. (1998) menemukan bahwa perusahaan yang diaudit oleh perusahaan Big Six, memiliki kemungkinan dilakukannya manajemen laba yang lebih rendah dibanding Non-Big Six. Hal ini dikarenakan Big Six mampu menginvestasikan lebih banyak dananya dalam pelatihan dan pengembangan auditornya serta memberikan pendalaman pemahaman industri lebih. Hal ini juga didukung oleh Chung et al. (2005), yang selain itu dikarenakan tekanan menjaga nama baik bagi Big Six lebih tinggi, sehingga auditor mempertahankan konservatisme demi menghindari adanya litigasi, membuat ketatnya auditor dalam menghindari dilakukannya manajemen laba.

Variabel kontrol keempat adalah ukuran perusahaan, dengan proksi total aset. Berbagai penelitian di Indonesia rata-rata menemukan bahwa perusahaan yang berukuran lebih besar memiliki kecenderungan lebih untuk melakukan manajemen laba. Menurut Astuti (2006), hal ini dikarenakan manajer perusahaan mencari cara untuk mengurangi laba, sehingga memberikan manfaat dalam penghematan pajak. Sedangkan menurut Moes (1987) dalam Budiasih (2008), alasan dari 


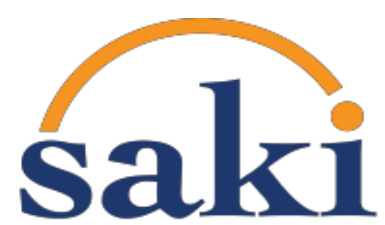

kecenderungan ini adalah perusahaan lebih besar seringkali lebih mungkin menjadi subjek pemeriksaan karena adanya pengawasan dari pemerintah yang lebih ketat.

Arus kas dari kegiatan operasi (OCF) adalah variabel kontrol terakhir. Proksi yang digunakan adalah arus kas dari kegiatan operasi dibagi dengan total aset perusahaan. Arus kas dari operasi menggambarkan kemampuan nyata perusahaan dalam menghasilkan dana bagi perusahaan (Chen et al., 2005). Apabila arus kas dari operasi tinggi, maka motivasi dilakukannya manajemen laba akan menurun karena perusahaan secara nyata memiliki kemampuan menghasilkan dana yang cukup.

\section{Model Penelitian}

Pengujian model menggunakan persamaan regresi linier berganda pada data panel, dan diolah menggunakan software Stata 12.0 .

Model 1 Penelitian menggunakan proksi struktur modal: debt-to-equity ratio

$$
\begin{aligned}
& Y_{i t}=\propto+\beta_{1} \cdot \text { der }_{i t}+\beta_{2} \cdot \text { board_size }_{i t}+\beta_{3} \cdot \text { board_indep }_{i t}+\beta_{4} \cdot \text { big }_{i t}+\beta_{5} \cdot \ln _{-} t a_{i t}+ \\
& \beta_{6} . o c f_{-} t a_{i t}+e_{i t}
\end{aligned}
$$

Model 2 Penelitian menggunakan proksi struktur modal: debt-to-asset ratio

$$
\begin{gathered}
Y_{i t}=\propto+\beta_{1} . \text { dar }_{i t}+\beta_{2} . \text { board_size } i t \\
\beta_{6} . o c f_{-} t a_{i t}+e_{i t}
\end{gathered}
$$

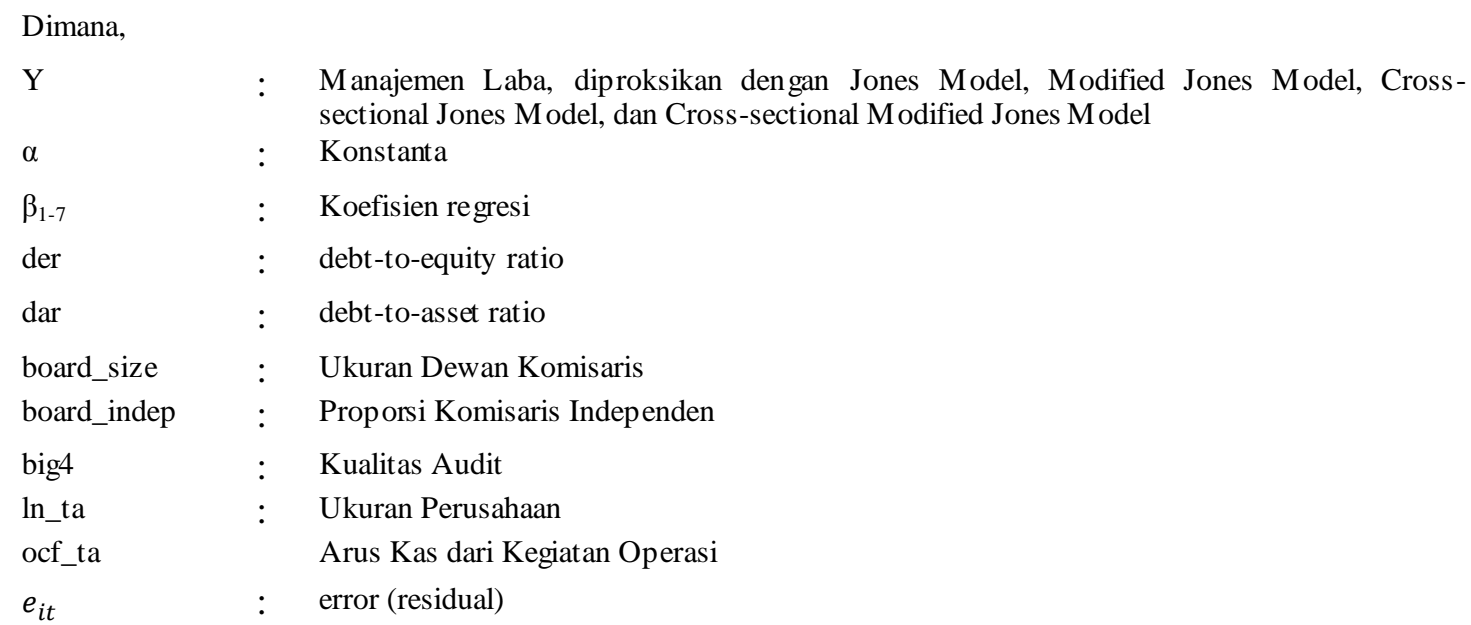




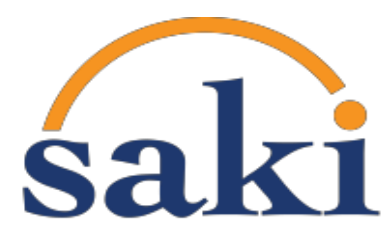

\section{Analisis Data}

Analisis data dilakukan dengan menggunakan regresi berganda dengan bantuan software statistic STATA. Pengujian asumsi klasik dilakukan sebelum pengujian regresi berganda. Uji asumsi klasik meliputi uji normalitas, uji multikolinearitas, uji autokore lasi, dan uji heteroskedastisitas.

\section{Hasil dan Pe mbahasan}

\section{Statistik Deskriptif}

Tabel berikut memperlihatkan karakter statistik dari variabel independen yang diuji, variabel kontrol, serta variabel dependen.

Tabel 2. Statistik Deskriptif Data

\begin{tabular}{|c|c|c|c|c|c|c|}
\hline Variabel & Mean & Std. Dev. & Min & Max & Skewness & Kurtosis \\
\hline Manajemen Laba Jones & $-5.45 \mathrm{E}-03$ & 0.11919 & -0.468157 & 0.459147 & .345739 & 6.488664 \\
\hline $\begin{array}{l}\text { Manajemen Laba } \\
\text { Modified Jones }\end{array}$ & -0.004962 & 0.119435 & -0.467889 & 0.460028 & .35917 & 6.471267 \\
\hline $\begin{array}{l}\text { Manajemen Laba Cross- } \\
\text { sectional Jones }\end{array}$ & -0.001421 & 0.0935918 & -0.332681 & 0.332681 & 0.2024634 & 5.202751 \\
\hline $\begin{array}{l}\text { Manajemen Laba Cross- } \\
\text { sectional Modified Jones }\end{array}$ & -0.000216 & 0.0945737 & -0.336529 & 0.339370 & 0.2559416 & 5.23239 \\
\hline Struktur Modal (DER) & 0.6639755 & 0.5712789 & 0 & 6.910166 & 2.143639 & 15.34618 \\
\hline Struktur Modal (DAR) & 0.2192067 & 0.1871126 & 0 & 0.860484 & 0.035011 & 0.606742 \\
\hline Ukuran Dewan Komisaris & 4.360938 & 1.890553 & 2 & 13 & 1.168607 & 4.215413 \\
\hline $\begin{array}{l}\text { Proporsi Independensi } \\
\text { Ko misaris }\end{array}$ & 0.4104635 & 0.1169387 & 0.17 & 1 & 1.82808 & 8.440349 \\
\hline Dummy Kualitas Audit & 0.414583 & 0.492778 & 0 & 1 & .3467641 & 1.120245 \\
\hline $\begin{array}{l}\text { Operating Cash Flow } \\
\text { (ocf/ta) }\end{array}$ & 0.069531 & 0.110964 & -0.289612 & 0.429457 & .4045595 & 4.483821 \\
\hline $\begin{array}{l}\text { Ukuran Perusahaan } \\
\text { (lnAset) }\end{array}$ & 14.0906 & 1.718634 & 9.266989 & 19.27946 & .2017704 & 2.654463 \\
\hline
\end{tabular}

Variabel independen yang diuji adalah struktur modal yang diproksikan dengan empat proksi: debt-toequity ratio (der) dan debt-to-asset ratio (dar). Kemudian, terdapat lima variabel kontrol: ukuran dewan komisaris (board_size), independensi dewan komisaris dengan proksi persentase komisaris independen dalam dewan (board_indep), kualitas audit diproksikan dengan dummy KAP Big Four (big4), arus kas dari kegiatan operasi (ocf), ukuran perusahaan yang diukur dengan total aset (ta. 


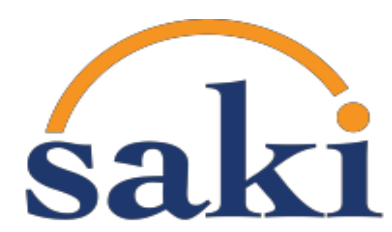

Kemudian variabel dependen manajemen laba diukur dengan empat model pendeteksi manajemen laba: Jones Model (1991), Modified Jones Model (1995), cross-sectional industrial model dari Jones Model dan Modified Jones Model.

\section{Hasil Uji Hipotesis}

Hasil regresi menunjukkan bahwa pengaruh dari struktur modal terhadap praktik manajemen laba mela lui akrual diskresioner pada perusahaan non-finansial yang terdaftar di BEI periode 2005-2014 bersifat negatif signifikan. Artinya semakin tinggi penggunaan utang sebagai sumber modal perusahaan, semakin rendah atau sedikit praktik manajemen laba yang dilakukan manajemen. Hal ini terlihat dari sepuluh model regresi yang dilakukan dengan proksi berbeda.

Tabel 3. Tabel Ringkasan Hasil Regresi Variabel Independen Struktur Modal

\begin{tabular}{|l|c|c|c|l|l|}
\hline $\begin{array}{c}\text { Proksi Variabel } \\
\text { Dependen }\end{array}$ & $\begin{array}{c}\text { Proksi Variabel } \\
\text { Independen }\end{array}$ & $\mathrm{P}>|\mathrm{t}|$ & Coef. & \multicolumn{2}{|c|}{ Keterangan } \\
\hline dac_jones & $d e r$ & $0.000^{*}$ & -0.02995 & Signifikan & Negatif \\
\hline dac_jones & $d a r$ & $0.000^{*}$ & -0.12259 & Signifikan & Negatif \\
\hline dac_mod & $d e r$ & $0.000^{*}$ & -0.02978 & Signifikan & Negatif \\
\hline dac_mod & $d a r$ & $0.000^{*}$ & -0.12285 & Signifikan & Negatif \\
\hline dac_jones_ind & $d e r$ & $0.000^{*}$ & -0.03116 & Signifikan & Negatif \\
\hline dac_jones_ind & $d a r$ & $0.000^{*}$ & -0.09599 & Signifikan & Negatif \\
\hline dac_mod_ind & der & $0.000^{*}$ & -0.02744 & Signifikan & Negatif \\
\hline dac_mod_ind & dar & $0.000^{*}$ & -0.09222 & Signifikan & Negatif \\
\hline
\end{tabular}

dac jones = discretionary accruals melalui Jones Model; dac_mod = discretionary accruals melalui Modified Jones Model dac_jones_ind = discretionary accmals melalui cross-sectional industrial Jones Model; dac_mod_ind = discretionary accruals melalui cross-sectional industrial Modified Jones Model; der = debt-to-equity ratio; dar = debt-to-asset ratio

* Signifikan pada 1\%; Sumber: Output Stata

Hasil pene litian sejalan dengan pene litian dari Chung et al. (2005) yang menyatakan dengan tingginya debt covenant, maka kecenderungan dipraktikannya manajemen laba justru menurun. Hal ini dilkarenakan saat debt covenant bertambah ketat, kontrol atas performa perusahaan juga meningkat. Penelitian ini juga konsisten dengan King dan Santor (2008). Meningkatnya proporsi penggunaan utang sebagai sumber modal meningkatkan fungsi kontrol, atau disebut control-enhancing mechanism, dimana timbul karena adanya risiko kebangkrutan yang tidak ada pada perusahaan yang hanya menggunakan ekuitas sebagai sumber dananya. Penelitian ini juga konsisten dengan penelitian terdahulu dari Becker et al. (1998); Chen et al. (2005); Jelinek (2007). 
Hasil dari penelitian memperlihatkan bahwa tekanan untuk mempertahankan performa perusahaan agar tidak melanggar debt covenant melalui dilakukannya manajemen laba lebih rendah dibanding tekanan dari bertambahnya pengawasan bagi manajemen, sehingga praktik manajemen laba justru dihindari. Karenanya, struktur modal mendemotivasi dilakukannya manajemen laba.

Struktur modal mengukur proporsi penggunaan utang terhadap ekuitas melalui debt-to-equity ratio, juga proporsi penggunaan utang terhadap total aset perusahaan melalui debt-to-asset ratio. Hasil penelitian yang menunjukkan pengaruh signifikan negatif dari struktur modal terhadap manajemen laba memiliki arti semakin tingginya struktur modal, yang berarti semakin besarnya proporsi penggunaan utang terhadap ekuitas (der) maupun total aset (dar), membuat kecenderungan praktik manajemen laba berkurang.

Penggunaan utang memiliki keunggulan dimana dapat memberikan penghematan bagi perusahaan, dimana bunga dari utang yang bersifat tax deductible expense. Selain itu, penggunaan utang sebagai sumber modal perusahaan tidak mempengaruhi struktur kepemilikan perusahaan, sehingga pemegang saham tidak perlu khawatir akan berkurangnya kontrol yang dimilikinya atas perusahaan. Karena itu, banyak perusahaan yang terus menggunakan utang dan mempertahankan performanya sesuai dengan persyaratan debt covenant agar terus dapat didanai oleh kreditor.

Persyaratan debt covenant adalah suatu perjanjian yang dibuat untuk melindungi kepentingan kreditor dari tindakan-tindakan manajer yang dapat merugikannya. Secara umum, debt covenant dibagi menjadi dua jenis (Healy \& Palepu, 1990). Pertama, affirmative covenants yang mengharuskan perusahaan yang berutang untuk melakukan hal yang sesuai persyaratannya, seperti persyaratan penyerahan laporan yang sudah diaudit kepada kreditor dengan suatu jangka waktu, mempertahankan status legalitas perusahaan selama masih berutang, atau juga memelihara kondisi keuangan perusahaan pada level tertentu. Kedua, negative covenants yang melarang perusahaan yang berutang untuk melakukan hal-hal tertentu, seperti melarang adanya pembayaran dividen kepada pemegang saham, tidak diperbolehkannya akuisisi atau merger selama masih berutang, melarang adanya pergantian manajemen perusahaan tanpa ijin, atau tidak diperkenankannya kondisi keuangan perusahaan mencapai suatu level.

Adanya debt covenant membuat kontrol atas performa perusahaan terutama dari segi keuangannya menjadi lebih ketat. Dari sisi kuantitatif, pengawas kinerja keuangan perusahaan bertambah, yakni adanya kreditor yang ikut mengontrol performa perusahaan melalui debt covenant. Sedangkan dari sisi kualitatif, pengawasan dari komisaris juga meningkat karena risiko kebangkrutan yang ikut meningkat. 


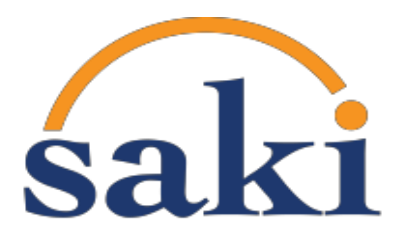

Meningkatnya kontrol atau pengawasan dari segi kuantitatif adalah bertambahnya kreditor sebagai pengawas, serta kualitatif adalah semakin ketatnya pengawasan karena risiko kebangkrutan yang lebih tinggi. Hal ini membuat ruang gerak manajemen laba bagi manajer berkurang. Sehingga, peningkatan penggunaan utang perusahaan membuat kemungkinan manajer untuk melakukan intervensi di saat menyusun laporan keuangan berkurang.

Tabel 4. Tabel Ringkasan Hasil Regresi Variabel Kontrol Uk uran Dewan Komisaris

\begin{tabular}{|c|c|c|c|c|c|}
\hline \multicolumn{6}{|c|}{$\begin{array}{l}\text { Variabel Kontrol Uku ran De wan Ko mis aris } \\
\text { Proksi = Ju mlah Dewan Ko mis aris }\end{array}$} \\
\hline $\begin{array}{c}\text { Proksi Variabel } \\
\text { Dependen }\end{array}$ & $\begin{array}{c}\text { Proksi } \\
\text { Variabel } \\
\text { Independen }\end{array}$ & $P>|t|$ & Coef. & \multicolumn{2}{|c|}{ Keterangan } \\
\hline dac_jones & der & 0.530 & $\begin{array}{r}0.001369 \\
1\end{array}$ & \multicolumn{2}{|c|}{ Insignifikan } \\
\hline dac_jones & dar & 0.514 & $\begin{array}{r}0.001271 \\
3\end{array}$ & \multicolumn{2}{|c|}{ Insignifikan } \\
\hline dac_mod & der & 0.541 & $\begin{array}{r}0.001326 \\
6\end{array}$ & \multicolumn{2}{|c|}{ Insignifikan } \\
\hline dac_mod & dar & 0.523 & $\begin{array}{r}0.001239 \\
7\end{array}$ & \multicolumn{2}{|c|}{ Insignifikan } \\
\hline dac_jones_ind & der & $0.005^{*}$ & $\begin{array}{r}0.002434 \\
3\end{array}$ & Signifikan & Positif \\
\hline dac_jones_ind & dar & $0.026 * *$ & $\begin{array}{r}0.001984 \\
1\end{array}$ & Signifikan & Positif \\
\hline dac_mod_ind & der & $0.004 *$ & $\begin{array}{r}0.002725 \\
5\end{array}$ & Signifikan & Positif \\
\hline dac_mod_ind & dar & $0.009 *$ & $\begin{array}{r}0.002414 \\
1\end{array}$ & Signifikan & Positif \\
\hline
\end{tabular}

dac_jones = discretionary accruals melalui Jones Model; dac_mod = discretionary accruals melalui Modified Jones Model; dac_jones_ind = discretionary accruals melalui cross-sectional industrial Jones Model; dac_mod_ind = discretionary accruals melalui cross-sectional industrial Modified Jones Model; der $=$ debt-to-equity ratio $;$ dar $=$ debt-to-asset ratio .

* Signifikan pada $1 \% * *$ Signifikan pada 5\%; Sumber: Output Stata

Hasil regresi menggunakan proksi manajemen laba yang agregat (bukan cross-sectional industrial) menunjukkan pengaruh dari ukuran dewan komisaris terhadap praktik manajemen laba adalah insignifikan. Sedangkan disaat menggunakan proksi manajemen laba yang telah di regresi crosssectional industrial, pengaruh dari dewan komisaris terhadap praktik manajemen laba adalah 


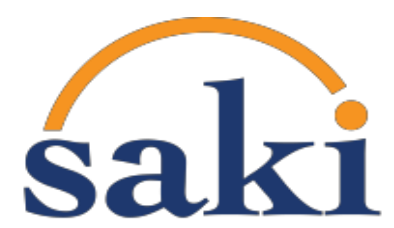

signifikan positif. Hasil ini berarti ukuran dewan komisaris yang semakin banyak tidak menjamin semakin efektifnya pengawasan atas perusahaan. Hasil penelitian mendukung bahwa tidak efektifnya pengawasan justru dapat memotivasi praktik manajemen laba.

Semakin banyak jumlah komisaris perusahaan bukan berarti pengawasan atas kinerja perusahaan semakin optimal. Jensen (1993) menemukan dalam penelitiannya bahwa jumlah komisaris yang optimal adalah tujuh atau delapan orang di Amerika Serikat. Acuan ini digunakan oleh peneliti di Indonesia, Widyaningdyah (2001) dalam menguji ukuran dewan komisaris. Hasil dari pengujian Widyaningdyah (2001) adalah ukuran dewan komisaris yang melebihi tujuh orang membuat pengawasan performa perusahaan menjadi tidak efektif karena memungkinkan tidak efisiennya pembagian tanggung jawab dan dapat membuat celah dilakukannya manajemen laba menjadi lebih lebar.

Tabel 5. Tabel Ringkasan Hasil Regresi Variabel Kontrol Proporsi Komisaris Independen

\begin{tabular}{|l|c|r|r|c|}
\hline \multicolumn{5}{|c|}{ Pariabel Kontrol Proporsi Ko misaris Independen } \\
\hline $\begin{array}{c}\text { Proksi Variabel } \\
\text { Dependen }\end{array}$ & $\begin{array}{c}\text { Proksi } \\
\text { Variabel } \\
\text { Independen }\end{array}$ & $\mathrm{P}>|\mathrm{t}|$ & Coef. & Keterangan \\
\hline dac_jones & der & 0.253 & -0.0260158 & Insignifikan \\
\hline dac_jones & dar & 0.286 & -0.0246239 & Insignifikan \\
\hline dac_mod & der & 0.258 & -0.0260128 & Insignifikan \\
\hline dac_mod & dar & 0.291 & -0.024627 & Insignifikan \\
\hline dac_jones_ind & der & 0.376 & -0.0113061 & Insignifikan \\
\hline dac_jones_ind & dar & 0.443 & -0.0099136 & Insignifikan \\
\hline dac_mod_ind & der & 0.425 & -0.0105608 & Insignifikan \\
\hline dac_mod_ind & dar & 0.485 & -0.009321 & Insignifikan \\
\hline
\end{tabular}

dac_jones = discretionary accruals melalui Jones Model; dac_mod = discretionary accruals melalui Modified Jones Model; dac_jones_ind = discretionary accruals melalui cross-sectional industrial Jones Model; dac_mod_ind = discretionary accruals melalui cross-sectional industrial Modified Jones Model; der = debt-to-equity ratio; dar = debt-to-asset ratio.

Sumber: Output Stata

Variabel kontrol proporsi komisaris independen menunjukkan tidak berpengaruh signifikan terhadap manajemen laba. Hasil pene litian sama dengan Siregar \& Utama (2008) dan Guna \& Herawaty (2010) yang juga menemukan bahwa proporsi komisaris independen tidak memiliki pengaruh signifikan pada praktik manajemen laba di Indonesia. Karena itu, berapapun jumlah komisaris independen yang ada 
pada perusahaan, pengawasan dari dewan komisaris tidak memiliki perbedaan pengaruh pada praktik manajemen laba.

Hal ini dikarenakan belum efektifnya pembagian tanggung jawab bagi komisaris independen. Karenanya, peran dari komisaris independen yang seharusnya dapat meningkatkan objektifitas pengawasan tidak dapat memberikan manfaat bagi perusahaan. Agustia (2013) mengemukakan masih adanya kendala bagi efektifnya pelaksanaan tugas bagi komisaris independen di Indonesia. Kendala tersebut adalah kurangnya integritas komisaris independen dalam meningkatkan kualitas pengawasan serta kompetensi yang masih kurang. Fenomena yang terjadi adalah pemilihan komisaris didasarkan adanya hubungan kedekatan dengan pemegang saham mayoritas.

Pengaruh proporsi komisaris independen yang tidak signifikan juga dapat dikarenakan motivasi dasar dari penambahan komisaris independen itu sendiri dalam dewan komisaris, yang dikarenakan untuk pemenuhan peraturan dari Surat Keputusan Direksi PT Bursa Efek Jakarta Nomor: Kep 305/BEJ/072004. Dalam surat ini, perusahaan yang tercatat dalam Bursa Efek Indonesia diwajibkan memiliki proporsi komisaris independen minimal 30\% dari jumlah komisaris perusahaan. Motivasi hanya untuk pemenuhan syarat ini dapat menyebabkan realisasi tugas dan pertanggungjawaban dari komisaris independen tidak dapat memberikan manfaat bagi perusahaan karena kurangnya motivasi dan integritas dari komisaris independen yang ditunjuk.

Tabel 6. Tabel Ringkasan Hasil Regresi Variabel Kontrol Kualitas Audit

\begin{tabular}{|c|c|c|c|c|}
\hline \multicolumn{5}{|c|}{$\begin{array}{c}\text { Variabel Kontrol Kualitas Audit } \\
\text { Proksi = Dummy KAP Big4 }\end{array}$} \\
\hline $\begin{array}{c}\text { Proksi Variabel } \\
\text { Dependen }\end{array}$ & $\begin{array}{c}\text { Proksi } \\
\text { Variabel } \\
\text { Independen }\end{array}$ & $P>|t|$ & Coef. & Keterangan \\
\hline dac_jones & der & 0.885 & -0.0007241 & Insignifikan \\
\hline dac_jones & dar & 0.748 & -0.0016722 & Insignifikan \\
\hline$d a c \_m o d$ & der & 0.883 & -0.0007388 & Insignifikan \\
\hline dac_mod & dar & 0.748 & -0.0016772 & Insignifikan \\
\hline dac_jones_ind & der & 0.738 & -0.0039373 & Insignifikan \\
\hline dac_jones_ind & dar & 0.673 & -0.00507 & Insignifikan \\
\hline dac_mod_ind & der & 0.609 & -0.0060148 & Insignifikan \\
\hline dac_mod_ind & dar & 0.562 & -0.0069766 & Insignifikan \\
\hline
\end{tabular}

dac_jones = discretionary accruals melalui Jones Model; dac_mod = discretionary accruals melalui Modified Jones Model; dac_jones_ind = discretionary accruals melalui cross-sectional industrial Jones Model; dac_mod_ind 


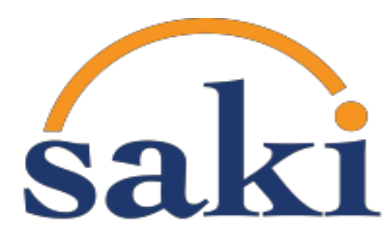

$=$ discretionary accruals melalui cross-sectional industrial Modified Jones Model $;$ der $=$ debt-to-equity ratio $;$ dar $=$ debt-to-asset ratio.

Sumber: Output Stata

Hasil regresi variabel kontrol kualitas audit menunjukkan hasil yang tidak signifikan terhadap manajemen laba. Hasil ini sesuai dengan penelitian dari Siregar \& Utama (2008) yang juga menemukan tidak adanya pengaruh yang berarti, baik perusahaan menggunakan jasa KAP Big4 ataupun bukan KAP Big4 dalam mengurangi praktik manajemen laba yang dilakukan perusahaan.

Hasil ini mengindikasikan bahwa peran dari audit dari KAP tidak mengurangi tendensi dilakukan atau tidaknya manajemen laba pada perusahaan. Peran auditor dalam mengaudit perusahaan adalah untuk meningkatkan kredibilitas laporan keuangan. Peningkatan kredibilitas dilakukan dengan berbagai prosedur yang bertujuan menemukan keabnormalan dan melakukan penyesuaian untuk meningkatkan kehandalan informasi keuangan didalamnya. Keberadaan auditor dan prosedur auditnya belum mampu memberikan batasan bagi manajemen untuk mengurangi praktik manajemen laba.

Tabel 7. Tabel Ringkasan Hasil Regresi Variabel Kontrol Ukuran Perusahaan

\begin{tabular}{|c|c|c|c|c|c|}
\hline \multicolumn{6}{|c|}{$\begin{array}{l}\text { Variabel Kontrol Uku ran Perusahaan } \\
\text { Proksi = logarit ma natural Total Aset }\end{array}$} \\
\hline $\begin{array}{c}\text { Proksi Variabel } \\
\text { Dependen }\end{array}$ & $\begin{array}{c}\text { Proksi } \\
\text { Variabel } \\
\text { Independen }\end{array}$ & $P>|t|$ & Coef. & \multicolumn{2}{|c|}{ Keterangan } \\
\hline dac_jones & der & $0.000 *$ & 0.0388629 & Signifikan & Positif \\
\hline dac_jones & dar & $0.000 *$ & 0.0394684 & Signifikan & Positif \\
\hline dac_mod & der & $0.000 *$ & 0.0390383 & Signifikan & Positif \\
\hline$\overline{d a c \_m o d}$ & dar & $0.000^{*}$ & 0.0396579 & Signifikan & Positif \\
\hline dac_jones_ind & der & 0.128 & 0.0089161 & \multicolumn{2}{|c|}{ Insignifikan } \\
\hline dac_jones_ind & dar & 0.119 & 0.0089629 & \multicolumn{2}{|c|}{ Insignifikan } \\
\hline dac_mod_ind & der & 0.139 & 0.0086642 & \multicolumn{2}{|c|}{ Insignifikan } \\
\hline dac_mod_ind & dar & 0.125 & 0.0088476 & \multicolumn{2}{|c|}{ Insignifikan } \\
\hline
\end{tabular}

dac_jones = discretionary accruals melalui Jones Model; dac_mod = discretionary accruals melalui Modified Jones Model; dac_jones_ind = discretionary accruals melalui cross-sectional industrial Jones Model; dac_mod_ind = discretionary accruals melalui cross-sectional industrial Modified Jones Model; der = debt-to-equity ratio; dar = debt-to-asset ratio.

* Signifikan pada 1\%; Sumber: Output Stata

Variabel kontrol ukuran perusahaan mempengaruhi manajemen laba secara signifikan dan positif disaat regresi dilakukan dengan proksi variabel dependen manajemen laba yang bersifat agregat (bukan cross-sectional industrial). Sedangkan dengan proksi variabel dependen manajemen laba yang cross-sectional industrial, ukuran perusahaan tidak memiliki pengaruh bagi praktik manajemen laba. 


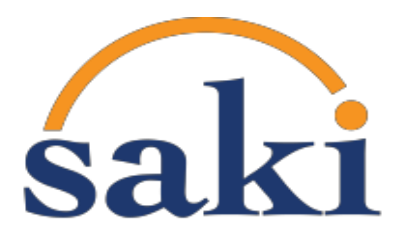

Hasil penelitian yang menunjukkan adanya pengaruh positif signifikan dari ukuran perusahaan terhadap praktik manajemen laba sejalan dengan penelitian dari Chen et al. (2005). Semakin besar ukuran perusahaan, maka kompleksitas dari akun dan pencatatannya menjadi semakin rumit, sehingga semakin banyak celah diskresi yang dapat digunakan manajemen sebagai sarana dilakukannya manajemen laba. Penelitian di Indonesia oleh Budiasih (2008) juga menemukan hasil yang serupa.

Namun pengaruh ukuran perusahaan pada manajemen laba yang diproksikan dengan cross-sectional industrial Jones Model dan cross-sectional industrial Modified Jones Model justru insignifikan. Artinya, dengan dikelompokan berdasarkan industri, ukuran perusahaan tidak menjadi faktor penentu semakin dilakukan atau tidaknya manajemen laba. Besarnya perusahaan memang memberikan sarana yang lebih banyak dan lebih kompleks, sehingga celah untuk dilakukannya manajemen laba lebih besar, namun pengawasan juga menjadi lebih tinggi karena lebih banyaknya calon investor dan analis yang ikut mengamati kinerja perusahaan. Sehingga semakin besar ukuran perusahaan tidak menjamin semakin besar kecenderungan dilakukannya manajemen laba, karena tidak semakin mudah bagi manajemen perusahaan untuk melakukan hal tersebut dengan pengawasan yang lebih banyak. Hasil ini sejalan dengan Christiani \& Nugrahanti (2014).

Tabel 8. Tabel Ringkasan Hasil Regresi Variabel Kontrol Arus Kas dari Kegiatan Operasi

\begin{tabular}{|l|c|c|c|c|c|}
\hline \multicolumn{5}{|c|}{ Variabel Kontrol Arus Kas dari Kegiatan Operasi } \\
\hline $\begin{array}{c}\text { Proksi Variabel } \\
\text { Dependen }\end{array}$ & $\begin{array}{c}\text { Proksi } \\
\text { Variabel } \\
\text { Independen }\end{array}$ & $\mathrm{P}>|\mathrm{t}|$ & Coef. & \multicolumn{2}{c|}{ Keterangan } \\
\hline dac_jones & der & $0.000^{*}$ & -0.97264 & Signifikan & Negatif \\
\hline dac_jones & dar & $0.000^{*}$ & -0.9857991 & Signifikan & Negatif \\
\hline dac_mod & der & $0.000^{*}$ & -0.9760298 & Signifikan & Negatif \\
\hline dac_mod & dar & $0.000^{*}$ & -0.9893293 & Signifikan & Negatif \\
\hline dac_jones_ind & der & $0.000^{*}$ & -0.7254878 & Signifikan & Negatif \\
\hline dac_jones_ind & dar & $0.000^{*}$ & -0.7320469 & Signifikan & Negatif \\
\hline dac_mod_ind & der & $0.000^{*}$ & -0.735149 & Signifikan & Negatif \\
\hline dac_mod_ind & dar & $0.000^{*}$ & -0.7426641 & Signifikan & Negatif \\
\hline
\end{tabular}

dac_jones = discretionary accruals melalui Jones Model; dac_mod = discretionary accruals melalui Modified Jones Model; dac_jones_ind = discretionary accruals melalui cross-sectional industrial Jones Model; dac_mod_ind = discretionary accruals melalui cross-sectional industrial Modified Jones Model; der = debt-to-equity ratio; dar = debt-to-asset ratio.

* Signifikan pada 1\%; Sumber: Output Stata 
Pengaruh dari arus kas dari kegiatan operasi perusahaan terhadap praktik manajemen laba adalah signifikan negatif. Semakin tinggi arus kas dari kegiatan operasi, semakin rendah kemungkinan dilakukannya manajemen laba. Arus kas dari kegiatan operasi menggambarkan kapabilitas dari perusahaan untuk menghasilkan dana yang likuid bagi operasional perusahaan. Sehingga, karena perusahaan telah mampu menghasilkan dana yang mencukupi operasional perusahaan, manajemen cenderung tidak melakukan manajemen laba. Hasil penelitian sejalan dengan Becker et al. (1998), Davis, Soo, \& Trompeter (2009), Chen et al. (2005), Maijoor \& Vanstraelen (2006), dan Siregar \& Utama (2008).

\section{Kesimpulan, Keterbatasan Penelitian, dan Implikasi}

Penelitian ini berhasil membuktikan adanya pengaruh signifikan dari struktur modal terhadap manajemen laba. Pengaruh signifikan tersebut bersifat negatif. Hasil ini konsisten saat penggunaan proksi manajemen laba dan proksi struktur modal yang berbeda. Hasil membuktikan semakin tinggi utang perusahaan, maka semakin kecil tendensi dilakukannya manajemen laba. Hal ini dikarenakan pengawasan yang meningkat dari kreditor atas performa perusahaan, sehingga diskresi manajemen untuk melakukan manajemen laba semakin terbatasi melalui ketatnya debt covenant perusahaan.

Penelitian ini tidak terlepas dari adanya keterbatasan berupa adanya survivorship bias, dari kriteria yang digunakan pada saat dilakukan purposive sampling. Survivorship bias timbul karena kriteria yang digunakan mengeliminasi kondisi perusahaan yang nyatanya ada pada populasi, yakni mengeliminasi perusahaan yang mengalami gejala kebangkrutan (nilai buku dari ekuitas adalah negatif selama periode penelitian), perusahaan yang baru listing dan yang mengalami delisting. Sehingga, perusahaan yang menjadi sampel merupakan perusahaan non-finansial yang tidak mengalami gejala kebangkrutan dan tidak mengalami permasalahan baru listing ataupun delisting. Karenanya, hasil dari penelitian hanya data diimplementasikan pada perusahaan dengan ciri tersebut. Penelitian selanjutnya dapat melakukan penelitian yang lebih mendalam dengan pemilihan sampel yang lebih spesifik atau terkhusus pada sampel yang sedang mengalami suatu fenomena tertentu, contohnya di saat perusahaan sedang mengalami gejala kebangkrutan, perusahaan akan listing, di tahun listing, atau delisting, atau juga saat terjadi corporate action, seperti merger dan akuisisi. Atau dapat pula disaat sedang ada perubahan peraturan yang dapat mempengaruhi struktur modal perusahaan secara signifikan.

Hasil penelitian ini diharapkan memberikan implikasi bagi Perusahaan, untuk dapat menjadi bahan masukan, terutama dalam menjaga struktur modal dengan lebih mempertimbangkan pemilihan 


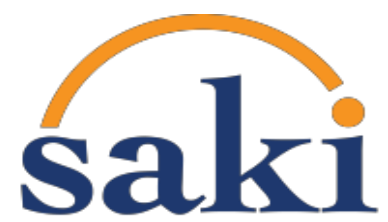

penggunaan sumber modal dari perspektif biaya dibandingkan dengan manfaatnya. Penggunaan struktur modal yang optimal dapat memberikan manfaat bagi perusahaan baik dari segi finansial (penghematan biaya pajak dan penurunan WACC) ataupun dari segi non-finansial (meningkatnya pengawasan yang membuat manajemen laba lebih rendah). Bagi Investor, Kreditor, dan pengguna laporan keuangan lainnya, untuk dapat dijadikan bahan pertimbangan yang bermanfaat untuk pengambilan keputusan berinvestasi atau pemberian pinjaman dengan mempertimbangkan kondisi perusahaan dengan struktur modalnya. Perusahaan yang telah banyak menggunakan utang hingga melebihi titik optimal dapat memiliki risiko kebangkrutan tinggi, yang justru dapat membuat investor dan kreditor tidak mendapatkan keuntungan dari menanam dana dan meminjamkan dana.

\section{Daftar Pustaka}

Agustia, D. (2013). "Pengaruh Faktor Good Corporate Governance, Free Cash Flow, dan Leverage Terhadap Manajemen Laba." Jurnal Akuntansi dan Keuangan 15(1): 27-42.

Astuti, D. S. P. (2006). "Analis is Faktor-Faktor yang Mempengaruhi Motivasi Manajemen Laba di Seputar Right Issue." Jurnal Ilmiah Akuntansi dan Bisnis 2(2).

Becker, C. L., DeFond, M. L., Jiambalvo, J, \& Subramanyam, K. R. (1998). "The Effect of Audit Quality on Earnings Management." Contemporary Accounting Research 15(1): 1-24.

Bradley, M., Jarrell, G. A., \& Kim, E. (1984). "On The Existence of An Optimal Capital Structure: Theory and Evidence." The Journal of Finance, 39(3), 857-878.

Budiasih, I. (2008). "Faktor-Faktor yang Mempengaruhi Praktik Perataan Laba." Jurnal Ilmiah Akuntansi dan Bisnis 4(1).

Chakraborty, S. \& Sen, A. (1975). "Optimal Capital Structure and Lower Cost of Capital: Towards an Operational Approach in the Indian Context." Economic and Political Weekly, 10(48), M106-M118.

Chen, K. Y., Elder, R. J., \& Hsieh, Y. (2007). "Corporate Governance and Earnings Management: The Implications of Corporate Governance Best-Practice Principles for Taiwanese Listed Companies." Journal of Contemporary Accounting \& Economics 3(2): 73-105.

Christiani, I \& Nugrahanti, Y. W. (2014). "Pengaruh Kualitas Audit Terhadap Manajemen Laba." Jurnal Akuntansi dan Keuangan 16(1): 52-62.

Chung, R., Firth, M., \& Kim, J. (2005). "Earnings Management, Surplus Free Cash Flow, and External Monitoring." Journal of Business Research 58(6): 766-776.

Davidson, R., J. Goodwin-Stewart, J., \& Kent, P. (2005). "Internal Governance Structures and Earnings Management." Accounting \& Finance 45(2): 241-267.

Davis, L. R., Soo, B., \& Trompeter, G. (2009). "Auditor Tenure and The Ability to Meet or Beat Earnings Forecasts." Contemporary Accounting Research 26(2): 517-548.

Dechow, P. M., Sloan, R. G., \& Sweeney, A. P. (1995). "Detecting Earnings Management." Accounting Review: 193-225. 


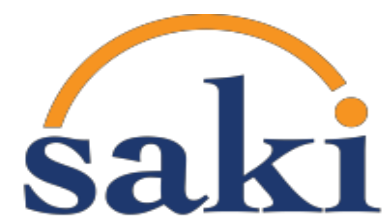

Direksi PT Bursa Efek Jakarta. (2004) "Keputusan Direksi PT Bursa Efek Jakarta No: Kep305/BEJ/07-2004 Tentang Peraturan Nomor I-A Tentang Pencatatan Saham dan Efek Bersifat Ekuitas Selain Saham yang Diterbitkan oleh Perusahaan Tercatat."

Frierman, M. \& Viswanath, P. (1994). "Agency Problems of Debt, Convertible Securities, and Deviations from Absolute Priority in Bankruptcy." The Journal of Law \& Economics, 37(2), 455-476.

Gardner, J. C., McGowan Jr, C. B., \& Moeller, S. E. (2013). "Using Coke-Cola and Pepsico to Demonstrate Optimal Capital Structure Theory." Journal of Finance and Accountancy, 14, 1.

Grossman, S. J. \& Hart, O. D. (1982). "Corporate Financial Structure and Managerial Incentives." The Economics of Information and Uncertainty, University of Chicago Press: 107-140.

Guna, W. I. \& Herawaty, A. (2010). "Pengaruh Mekanisme Good Corporate Governance, Independensi Auditor, Kualitas Audit dan Faktor Lainnya Terhadap Manajemen Laba." Jurnal Bisnis dan Akuntansi 12(1): 53-68.

Haugen, R. \& Senbet, L. (1988). "Bankruptcy and Agency Costs: The ir Significance to the Theory of Optimal Capital Structure." The Journal of Financial and Quantitative Analys is, 23(1), 27-38.

Healy, P. M. \& Palepu, K. G. (1990). "Effectiveness of Accounting-Based Dividend Covenants." Journal of Accounting and Economics 12(1-3): 97-123.

Healy, P. M. \& Wahlen, J. M. (1999). "A Review of The Earnings Management Literature and Its Implications for Standard Setting." Accounting Horizons 13(4): 365-383.

Hill, C. W., \& Jones, T. M. (1992). "Stakeholder-Agency Theory." Journal of Management Studies, 29(2), 131-154.

Jaggi, B., Leung, S., \& Gul, F. (2009). "Family Control, Board Independence and Earnings Management: Evidence Based on Hong Kong Firms." Journal of Accounting and Public Policy 28(4): 281-300.

Jeanjean, T. (2000). "Corporate Governance and Earnings Management." 24th Congress of The European Accounting Association, PricewaterhouseCoopers Doctoral Colloquium, 18-23 April 2001, Athens, Greece.

Jelinek, K. (2007). "The Effect of Leverage Increases on Earnings Management." The Journal of Business and Economic Studies 13(2): 24.

Jensen, M. C. (1993). "The Modern Industrial Revolution, Exit, and The Failure of Internal Control Systems." The Journal of Finance 48(3): 831-880.

Kesuma, A. (2009). "Analisis Faktor yang Mempengaruhi Struktur Modal Serta Pengaruhnya Terhadap Harga Saham Perusahaan Real Estate yang Go Public di Bursa Efek Indonesia." Jurnal Manajemen dan Kewirausahaan (Journal of Management and Entrepreneurship) 11(1): pp. 38-45.

Kim, B. H., Lisic, L. L., \& Pevzner, M. (2011). "Debt Covenant Slack and Real Earnings Management." Working Paper. American University.

Kim, J. \& Yi, C. H. (2006). "Ownership Structure, Business Group Affiliation, Listing Status, and Earnings Management: Evidence from Korea." Contemporary Accounting Research 23(2): 427-464.

King, M. R. \& Santor, E. (2008). "Family Values: Ownership Structure, Performance and Capital Structure of Canadian Firms." Journal of Banking \& Finance 32(11): 2423-2432.

Klein, A. (2002). "Audit Committee, Board of Director Characteristics, and Earnings Management." Journal of Accounting and Economics 33(3): 375-400. 
Longhofer, S. D., \& Peters, S. R. (2004). "Protection for Whom? Creditor Conflict and Bankruptcy." American Law and Economics Review, 6(2), 249-284.

Maijoor, S. J. \& Vanstraelen, A. (2006). "Earnings Management within Europe: The Effects of Member State Audit Environment, Audit Firm Quality and International Capital Markets." Accounting and Business Research 36(1): 33-52.

Mao, C. X. (2003). Interaction of Debt Agency Problems and Optimal Capital Structure: Theory and Svidence. Journal of Financial and Quantitative Analysis, 38(02), 399-423.

Modigliani, F. \& Miller, M. H. (1963). "Corporate Income Taxes and The Cost of Capital: A Correction." The American Economic Review 53(3): 433-443.

Omid, A. M. (2012). "Type of Earnings Management and The Effects Debt Contracts, Future Earnings Growth Forecast and Sales Growth: Evidence from Iran." School of Doctoral Studies (European Union) Journal: 7-16.

Robichek, A., \& Myers, S. (1966). "Problems in the Theory of Optimal Capital Structure." The Journal of Financial and Quantitative Analysis, 1(2), 1-35. doi:1.

Scott, J. (1976). "A Theory of Optimal Capital Structure.” The Bell Journal of Economics, 7(1), 3354. doi:1.

Siregar, S. V. \& Utama, S. (2008). "Type of Earnings Management and The Effect of Ownership Structure, Firm Size, and Corporate-Governance Practices: Evidence from Indonesia." The International Journal of Accounting 43(1): 1-27.

Widyaningdyah, A. U. (2001). "Analis is Faktor-Faktor yang Berpengaruh Terhadap Earnings Management pada Perusahaan Go Public di Indones ia." Jurnal Akuntansi dan Keuangan 3(2): pp. 89101.

Xie, B., Davidson, W. N., DaDalt, P. J. (2003). "Earnings Management and Corporate Governance: The Role of The Board and The Audit Committee." Journal of Corporate Finance 9(3): 295-316. 